\title{
病棟平面と看護師の看護負担感の関係についての研究 STUDY ON THE RELATION BETWEEN HOSPITAL WARD PLAN AND NURSES' BURDEN-FEELING
}

\author{
上谷ひとみ*，山田あすか**，山下哲 郎***，熊川寿 郎**** \\ Hitomi KAMIYA, Asuka YAMADA, Tetsuro YAMASHITA \\ and Toshiro KUMAKAWA
}

\begin{abstract}
This study clarifies the relationship between hospital ward layout and nurses' perception of burden, while also verifying the practical convenience of multiple-corridor layouts, which have come to be considered the innovative floor plan for wards.the survey respondents preferred a layout that features a central corridor and centrally located nurse station from among the various types of ward layouts. The multiple-corridor model, currently considered the innovative layout for hospital wards, cannot necessarily be described as beneficial from the perspective of reducing nurses' perception of burden. These results differed from the findings of research that analyzed volumes of nurse traffic.
\end{abstract}

Keywords: Hospital ward planning, Nurses' burden-feeling,Hospital ward plan type

病棟平面, 看護負担感, 病棟平面類型

\section{1. 研究の背景と目的}

\section{1 研究の背景}

病棟の平面構成（所室配置等含めたプランニング, 以下, 病棟平面） は多様である ${ }^{1)}$ 。平面構成は, 敷地・周辺環境の制約などの外的条件 の他に, 患者の疾患構成や年齢層などの属性, 病棟 (看護単位)の規模, 診療科, 病院の理念などに即して選択されている。病棟は, 一般的 に看護師が主体となって患者の療養生活を支える場として認識され ており ${ }^{2 ）}{ }^{3)}$, 看護師の病棟での看護負担に関しては, 看護動線に着 目した看護量調査による病棟平面の評価・検証などの視点による, 建築計画分野や医療・看護分野での研究蓄積がある。こうした主に 看護動線の効率性（移動距離に係る物理的・身体的な負担, 時間効率) に着目した研究蓄積に対して, 看護や介護の現場ではスタッフの心 理的疲労も問題視されている。例えば同じ距離を歩いていても，建 築的環境や運営，また個人によって疲労の感じられ方が異なる可能 性がある。しかし, 看護師が日頃の看護業務時に感じている看護負 担の感覚（以下，看護負担感）の視点では，病棟平面はこれまで評 価されてこなかった。そこで, 今後の病棟平面のあり方の検討に際 しては，スタッフの物理的・身体的負担のみならず，スタッフが “身 体的負担や心理的負担をどう感じているか”を勘案した建築計画上 の配慮や検証が必要と考える。本稿では，これを看護負担感と呼ぶ。

\section{2 関連する既往研究と本稿の位置づけ}

建築計画分野では一般病棟に㧍ける看護業務のしやすさ，効率性
について, 次に挙げるような既往研究がなされている。伊藤誠ら ${ }^{4)}$ は適切な看護単位規模をその診療種別ごとに考え, それぞれの大き さを考える際のモデル図を提示し, 診療種別ごとの適切な看護単位 規模を示している。また同著者ら ${ }^{5)}$ はプロット調査により看護諸室 の性質を明らかにし，ナースステーション（以下，NS）の位置の重 要性についても述べている。さらに, 長澤泰 ${ }^{6)}$ は夜勤における看護 師の動きを調查し，日勤との動きに違いがないことを明らかにした。 同氏 ${ }^{7)}$ は病棟看護師の病室訪問頻度について診療科別，勤務時閒別 など様々な要因を受けて変化はするものの, 総合的にみると值が近 似しており, 病棟ごとの看護師の勤務体制との関連を示唆している。 また, 谷口元ら ${ }^{8)}$ は看護動線の実態把握を行い, 調查病棟の患者の 配置換えによる動線量の改善，平面モデルを変更した場合の動線量 の予測等を行った。また, 病棟の建築計画の基礎的な部分以外にも 近年では, 中野明ら ${ }^{91}$ や河合慎介ら ${ }^{10)}$, 鳥山亜紀ら ${ }^{11)}$ による分散看 護拠点の機能や与える影響等についての研究がなされている。

これらに対して，看護負担感の観点からは，特に病院管理学会で 3 交替制から 2 交替制に転換した病棟看護師の疲労に関する調查や 看護師の職業満足に関する研究などストレスや負担に関する研究が 多数行われている。ここでは, しばしば職業性ストレス簡易調査票 が用いられている ${ }^{12)}$ 。

筆者らは栃木県下の内科 - 外科 - 循環器科 - 呼吸器科 - 消化器科 · 整形外科等の標榜診療科を持つ病院を対象とした, 病棟平面による

\footnotetext{
当時 東京電機大学大学院未来科学研究科建築学専攻 修士 (工学)

** 東京電機大学未来科学部建築学科 准教授 ·博士 (工学)

*** 工学院大学建築学部建築学科 教授 · 博士 (工学)

**** 国立保健医療科学院医療・福祉サービス研究部 部長·博士(医学)
}

Graduate School of Architecture, School of Science and Technology for Future Life, Tokyo Denki University, M. Eng.

Assoc. Prof., Department of Architecture, School of Science and Technology for Future Life, Tokyo Denki University, Dr. Eng.

Prof., Department of Architecture, Faculty of Architecture, Kogakuin Univ., Dr. Eng. Director, Department of Health and Welfare Services, National Institute of Public Health, Ph. D. 
看護師の負担感への影響を調べた既報 ${ }^{13)}$ で, 病棟平面が看護負担感 に影響を及ぼす可能性を示唆した。本稿では, 既報にて調查対象が 限定的であるために行えなかった分析などを含めて分析する。また， 病棟平面による看護師の負担感への影響を検証する事を目的とする。 その際, 既往研究の知見に基づき, 診療科による差異やNS の位置, 患者の重症度，ナースコーナー（以下，NC）の有無，勤務体制（2 交代／3交代）を分析項目に加え, 日勤と夜勤の別については特に 区別して問う項目を立てないこととする。また, 病棟平面計画の変 遷より発展型として考えられてきた複廊下型の平面構成 ${ }^{14)}$ であるが, 看護負担感の観点から評価の検証は行われてきていない。本研究で はその点についても，分析・検証を行う。

\section{2. 調査概要}

\section{1 調查対象}

関東圈全域（東京都・千葉県・神奈川県・埼玉県・栃木県・茨城県 $・$ 群馬県の 1 都 6 県) の上記 6 診療科の病棟を持つ全病院、計 1287 病 院を対象に，郵送回答方式によるアンケート調査を行った（表 1 )。 結果, 送付した 1287 病院のうち, 110 病院の回答を得た ${ }^{\text {注 } 2) 。 ~}$

\section{2 調査の方法}

調査でのアンケート用紙は 1 病棟につき以下の 3 種類を用いた。

・アンケート用紙 A：診療科種別や看護師の勤務体制等の病棟全体 の運営状況を問う。

・アンケート用紙 B : 病床数や患者の属性（救護区分, 年齢, 男女比） $\mathrm{NC}$ の有無等の病棟の運営状況を問う。

・アンケート用紙 C ：病棟に勤務する看護師による, 病棟平面や看 護負担感への評価を 7 段階評価で問う。対象者は, 各病棟 5 人の 看護師をランダムで選んでいただくよう依頼した ${ }^{\text {注3)。アンケート }}$ C の質問項目は表 2 の通りで，看護師の負担感を，業務内容や人間 関係など職場の運用的要因によるものと, 病棟平面が間接的にも たらすものとの両面から捕捉することを試みた。項目のうち, “ス トレスに関する項目” は職業性ストレス簡易調查票 ${ }^{12)}$ の項目を用 いた注4)。“動線や見守りのしやすさに関する項目”は，物理的・ 運用的狭義には環境への評価だが, 広義にはこのようなことがら から閒接的・直接的に感じているストレスの多塞と捉えられる。 これらの項目には, 既往研究で検討されてきたことがらを次のよ うに反映した。人と物の動線の効率性に関する評価：(10機材や物 品をスムーズに動かせる, (16)移動動線には無駄がない, (18いつも 急がずゆったりと移動できる。看護記録のとりやすさ : (11)看護記

\section{表 1 アンケート調査概要}

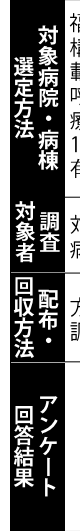

福祉・保険・医療情報のサイト：福祉医療機 構 WAM NET< http://www.wam.go.jp/>に揭 載された, 関東圈」の「内科, 外科, 堛噮器科, 療科を屯つ病院」計 1287 病院。

1287病院中, 110 病院の返信存得た。(うち。 有効回答 102 病院，返信率約 $8 \%)$

対象病院/病棟の運営状況がわかる管理者， 病棟看護師長また病棟に勤務する病棟看護師

方法：配布・回収はいずれも郵送 調査時期 : 2013 年 $6 \sim 8$ 月

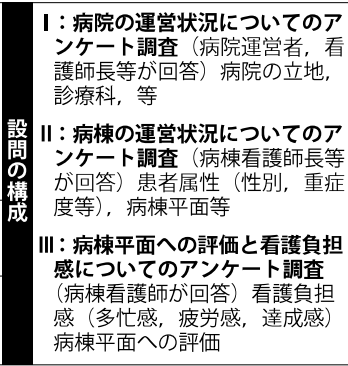

110 病院，のべ 314 病棟（内科 164 ，外科 73 ，循環器科 44 ，呼吸器科 40 ，消 化器科 52 ，整形外科 72 )。

診療科ごとにそれぞれ以下のアンケートCへの回答を得た（内科 840 人，外科 395 人，循環器科 226 人，呼吸器科 205 人，消化器科 276 人，整形外科 395 人) 。
録を書く時間はある。見守りのしやすさ：(17)見守り・観察はしや すい。電子カルテや NC の導入について : 13電子カルテは活用でき ている，(14)ナースステーション以外の看護拠点を活用できている。 休息について：(12)休み時間は十分に取れている。仕事量の緩急や 変化について : (15)日々の看護業務にあまり変化がない。

口分析対象分析対象と寸る病棟は, 110 病院, のべ 314 病棟（内 科 164 , 外科 73 , 循環器科 44 , 呼吸器科 40 , 消化器科 52 , 整形外科 72) である。この数字には，混合病棟の重複が含まれており，例え ば内科病棟と記載する際には“内科の看護を行う病棟”の意である注 5)。また，診療科ごとにそれぞれ以下のアンケートCへの回答を得た (内科 840 人, 外科 395 人, 循環器科 226 人, 呼吸器科 205 人, 消化 器科 276 人, 整形外科 395 人)。

\section{3 分析の方法}

一般に病棟平面の構成検討時には見通しと動線の長さが重視され る。本稿では, 病棟平面の空間レイアウトのうち病室と廊下, NS, その他の諸室の位置関係に着目し，アンケートで得られた病棟平面 図を図 1 のように【中廊下 NS 中央】・【中廊下 NS 端】・【複廊下 NS 中 央】・【複廊下 NS 端】, 中廊下型と複廊下型が複合した【中 + 複 NS 中

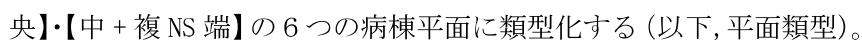
そして，アンケート結果を基に病棟平面，看護師の属性等を踏まえ た病棟平面と看護負担感の関係を分析する。なお，医療福祉施設を 設計者が紹介する日本医療福祉建築協会『情報シート集』によれば, 過去 5 年の傾向 ${ }^{15)}$ では複廊下型病棟の占める割合が最も高い (図 1 )。

\section{3. 評価項目と看護師の勤務に関連する諸条件, 病棟平面との関連 3.1 評価項目と看護師の勤務に関連する諸条件}

アンケート用紙 C の評価項目と看護師の勤務に関連寸る諸条件（勤 務環境, 患者属性, 病棟環境, 看護師属性）との関連をみる（表 2 , 縦軸の A)。電子カルテの有無と「13電子カルテは活用できている」 の項目間に相関比 $\eta^{2}=0.50^{\text {注6) }}$ の [やや強い関連 $]$ が，日勤勤務時間 と「(1)仕事量が多く負担である」,「11)看護記録を書く時間はある」, 「12休み時間は十分とれている」の項目間に $\eta^{2}=0.23, \quad \eta^{2}=0.24, \quad \eta$ ${ }^{2}=0.21$ の [やや弱い関連］がみられる。年齢と「113)電子カルテは活 用できている」の項目閒に $\eta^{2}=0.20$ の[非常に弱い関連]がみられるが， 「16移動動線には無駄がない」や「17)見守り観察はしやすい」等の動 線に関する項目と, 看護師の勤務に関連する諸条件（表 2 , 縦軸の A） との間に関連はみられない。このため, 既報 ${ }^{13)}$ では看護師属性の影 響が認められたが, サンプル数の増加によってこうした看護師属性

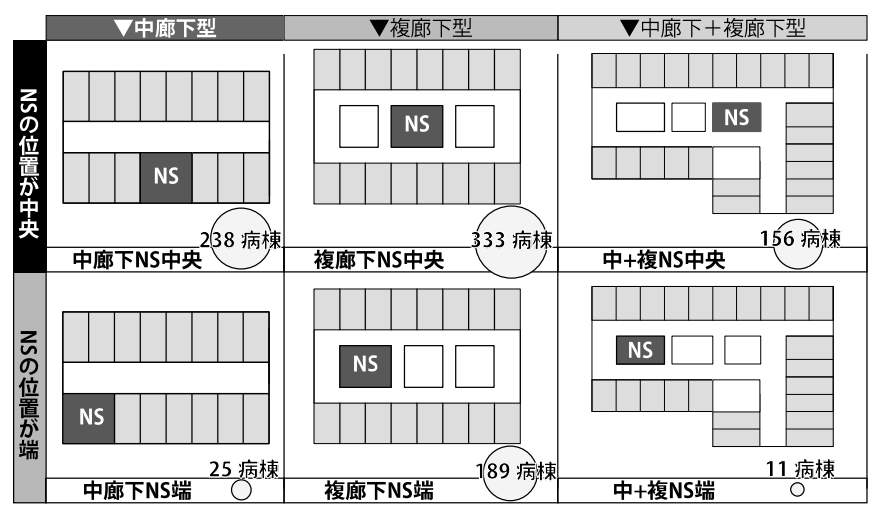

図 1 病棟平面の類型化 
の影響が相殺されていると考えられ, 以下の分析では看護師属性に よる場合分け等は行わないこととする。

\section{2 内科, 外科に限定した評価項目と病棟平面の関連}

伊藤誠ら ${ }^{4)}$ が診療種別ごとの看護規模の差異を指摘しているため, 診療科による差異を考慮した分析を行う。今回は，相対的にみてサ ンプル数が多い内科 (164 病棟, 840 看護師), 外科 (73 病棟, 395 看護師）の看護師について評価項目と病棟平面の関連をみる（表 2 , B)。特に動線や使いや寸さに関連した項目については，内科の看護 師で, NS の位置と「(5)作業環境はよい」の項目間にクラメールの連 関係数 $\mathrm{V}=0.15^{\text {注 } 7)}$ (表 $2[1]$ ), 平面類型 4 分類と「(3)仕事上での 身体的負担が小さい」の項目間にV $=0.19, 「$ (16)移動動線には無駄が ない」の項目間に $\mathrm{V}=0.21$ の [非常に弱い関連］がみられる（表 2 [2] [3])。NS の位置が中央の場合（図 2 [1]）と，【中廊下 NS 中央】 の平面類型の場合（図 2 [2] [3])，負担感が軽いとの回答の割合が
比較的高い。外科の看護師では，平面類型 4 分類と「(16)移動動線に は無駄がない」の項目間に $\mathrm{V}=0.25 に[$ やや弱い関連 $]$ がみられ（表 $2[4])$,【中廊下 NS 中央】の看護師で負担感が軽いとの回答が比較 的多小(図 $2[4])$ 。

\section{3 患者の条件を限定した評価項目と病棟平面の関連}

これまでの分析で評価項目と「16移動動線には無駄がない」や「17 見守り観察はしやすい」等の動線に関する項目間には明確な関連が みられなかった。谷口元ら ${ }^{8)}$ の既往研究では, 重症患者の有無が看 護師の動線量に影響を与えることが報告されているため，患者の条 件を限定し, 再度分析を行う注 8 )。看護師 1 人あたり病床数（許可 病床数 $\div$ 看護師の数） と，患者の平均在院日数について，上位 $25 \%$ (四分位) を「多い」，下位 $25 \%$ を超え上位 $25 \%$ 未満の中間值を「中 間」, 下位 $25 \%$ を少ない」とした。また，患者の重症度は救護区分 注9)による分類により, 独歩を軽度, 護送を中度, 担送を重度とした。
表 2 評価項目と看護師の勤務に関連する諸条件, 病棟平面との関連

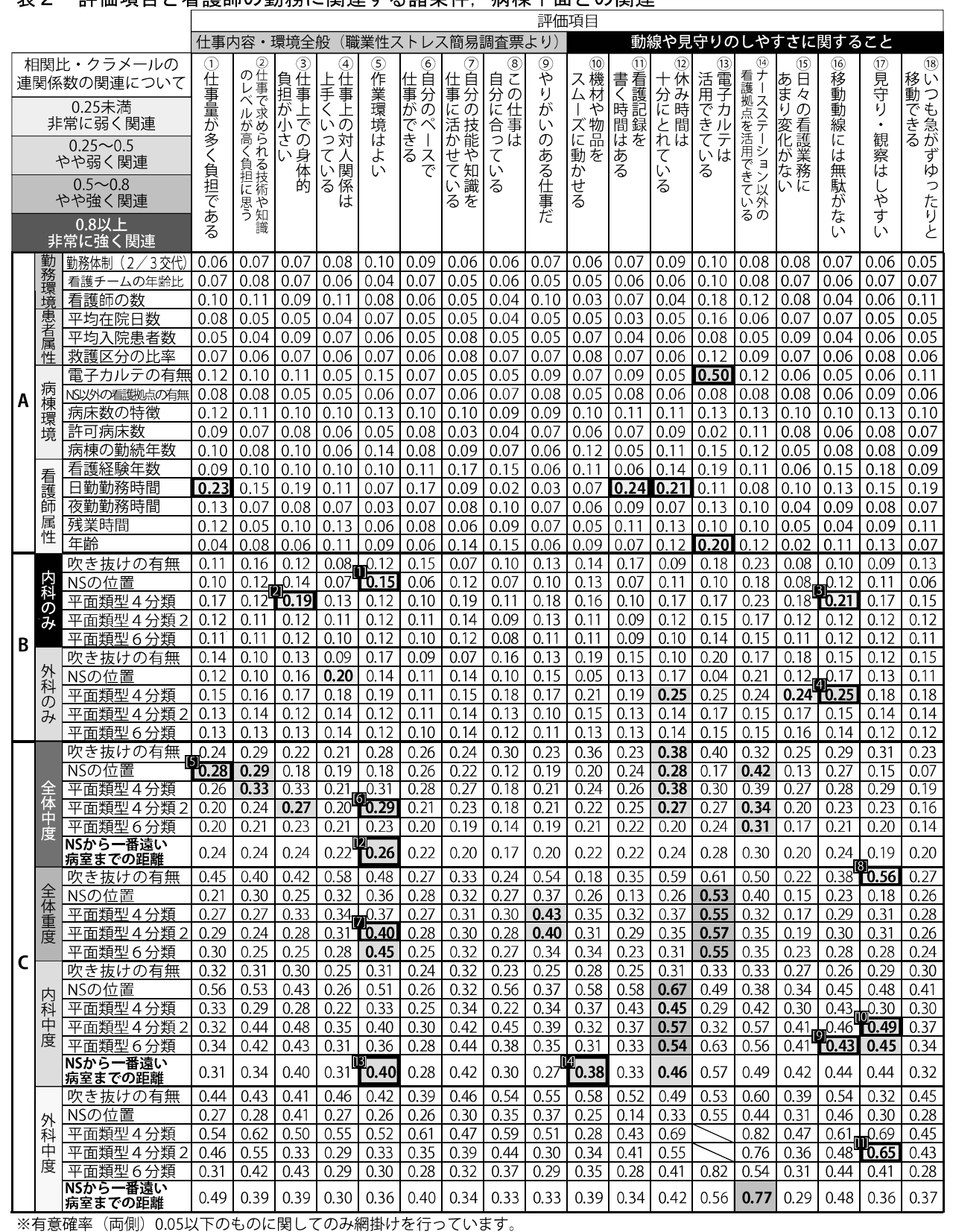

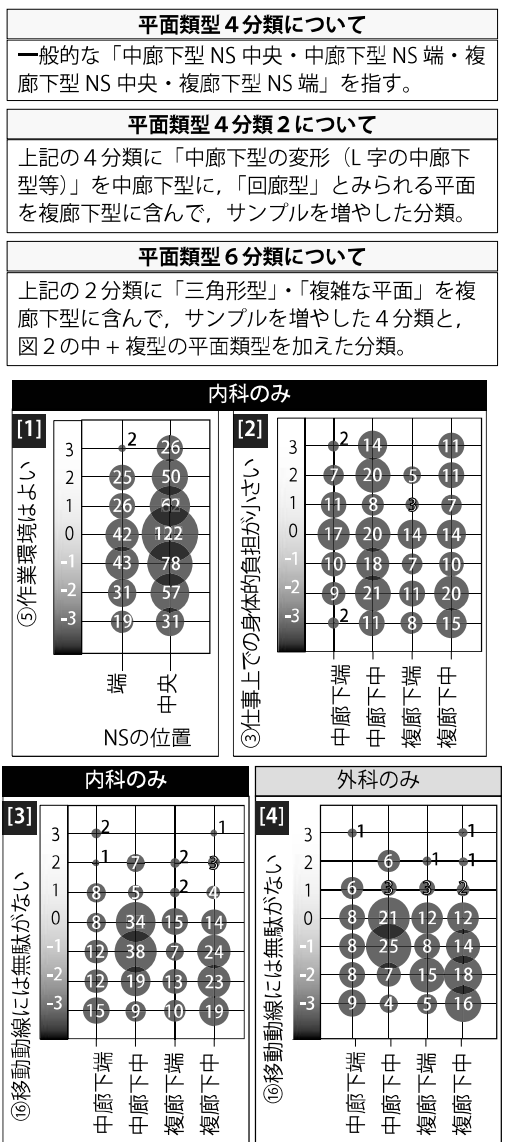

図 2 2 変量のバブルチャート

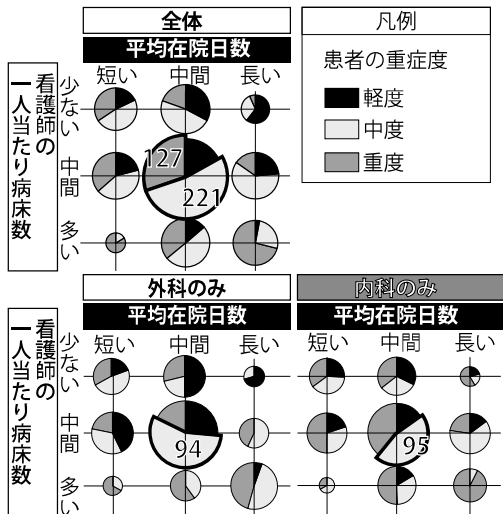

図 3 条件を限定した場合の数 
これらの定義を踏まえ, 図 3 のように, 患者の「平均在院日数が中間, 看護師の一人あたり病床数が中間, 患者の重症度が中度の条件」の 病棟に勤務する看護師 221 人 (以下, 全体中度), 「上記内容のうち 患者の重症度が重度」の病棟に勤務する看護師 127 人（以下，全体 重度),「全体中度を内科に限る」の条件に該当寸る看護師 95 人 (以下, 内科中度),「全体中度を外科に限る」の条件に該当する看護師 94 人(以 下，外科中度）の回答と病棟平面との関連をみる（表 $2 \mathrm{C}$ )。

1）患者属性が全体中度, 全体重度, 内科中度, 外科中度の場合の 評価項目と病棟平面の関連

全体中度 : NS の位置と「(1)仕事量が多く負担である」の項目間にV $=0.28$ の [やや弱い関連 $]$, 平面類型 4 分類 2 と「5)作業環境はよい」 の項目間に $\mathrm{V}=0.29$ の [やや弱い関連］がみられる（表 $2[5][6]) 。$ 【NS が中央】と,【中+複 NS 中央】で負担感が軽い看護師が比較的 多い(図 4 [5][6])。

全体重度 : 平面類型 4 分類 2 と「(5)作業環境はよい」の項目間に $\mathrm{V}$ $=0.40$ の [やや弱い関連 $]$, 吹き抜けの有無之「17見守り・観察 はしやすい」の項目間にV $=0.56$ の [やや強い関連 $]$ がみられる(表 $2[7][8])$ 【複廊下 NS 中央】の場合に負担感が軽い看護師の割 合が比較的高く，また複廊下のうち吹き抜けがある病棟の場合に 負担感が軽い看護師の割合が比較的多い（図 4 [7] [8])。

内科中度 : 平面類型 6 分類と「16移動動線には無駄がない」の項目 間に $V=0.43$ の [やや弱い関連，平面類型 4 分類 2 と「17 見守り・ 観察はしやすい」の項目間にV $=0.49$ の [やや弱い関連 $]$ がタら れる（表 2 [9]［10]）。どちらも【中廊下 NS 中央】では，負担感 が軽い看護師の割合が比較的多いことが分かる（図4 [9] [10])。

外科中度 : 平面類型 4 分類 2 と「17見守り・観察はしやすい」の項 目間に $\mathrm{V}=0.65$ の $[$ や強い関連］がみられる（表 2 [11]）。【中 廊下 NS 中央】では，負担感が軽い看護師の割合が比較的多いこと が分かる（図４[11]）。内科中度と, 概ねの傾向は類似している。

2 ）患者属性：全体中度, 内科中度の場合の評価項目と NS から一番 遠い病室までの距離との関係

NS から一番遠い病室までの距離（以下，最長距離。廊下の中央ラ インを積算）と患者の条件を限定した場合の特に動線に関する評価 項目との関連をみる（表 $2 \mathrm{C}$, 患者条件を限定した各条件の最下部記 載)。動線に関する項目との相関は，上記 1 ）のうち全体重度と，外 科中度では明確にはみられないため（表 $2 \mathrm{C}$ ), この分析では取り上 げていない。分析ではアンケート回収時に得られた病棟平面図のう ち, 距離等を測れる図面のみを使用した。寸法記載のない図面は 4 床室の間口を $5800 \mathrm{~mm}^{\text {注 }}{ }^{10)}$ と仮定し，縮尺を合わせた。

口最長距離と評価の関係 総じて, 最長距離と移動負担感への評 価項目 (16), 見守り・観察への負担感177との間には明確な関連はみら
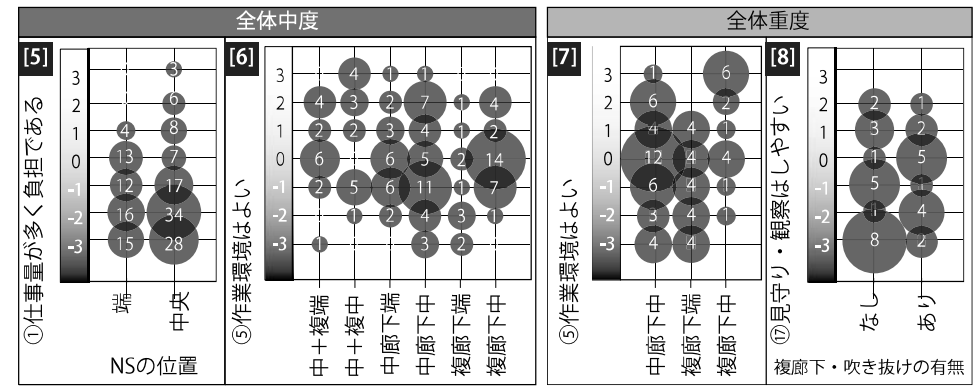

図 $4 \quad 2$ 変量の関係のバブルチャート
れない。条件によっては関係が認められ, [全体中度]にて(表 2 [12])， 最長距離と「5(作業環境はよい」の項目間に $\mathrm{V}=0.26$ の [やや弱い 関連］がみられる。図 5 [12］より，全体的に最長距離が長い場合 に作業環境への評価值が低く, 最長距離が短い場合に評価值が高い 傾向がみられた。しかし，最長距離が短い場合でも，評価值が低い 回答者もいる。［内科中度］にて（表 2 [13］［14]）, 最長距離と「5) 作業環境はよい」の項目間に $V=0.40, 「 10$ 機材や物品はスムーズに 動かせる」の項目間にV $=0.38$ の [やや弱い関連］がみられる。図 5 [13］［14］より全体中度と同じく, 総じて最長距離が短い場合に 評価が高い傾向がみられた。しかし，作業環境への評価は全体中度 と同様に最長距離が短くても評価值が低い回答者もみられる ([13])。

口病棟平面類型との関連図 6 に, 表 2 で最長距離との間に関連 がみられた項目に関し, 平面類型ごとに詳細を示した。また, 最長 距離（数量データ）と評価（順序尺度カテゴリデータ）であるが, 2 変量の関係の分布の様子をおおおおかに捉えるため，信頼楕円 $90 \%$ の分布範囲を点線で囲んだ。

[全体中度]·「5)作業環境はよい」と最長距離（表 2 , 図 6 [12]）【複 廊下 NS 中央】,【複廊下 NS 端】は最長距離が短い場合に(5)作業環境 はよい,の評価が高い傾向がみられ,【中+複 NS 端】,【中廊下 NS 中 央】、【中廊下 NS 端】では最長距離と評価に関連がみられない。【中+ 複 NS 中央】は, 最長距離が $30 \mathrm{~m}$ までに分布し, 他の平面類型に比心゙ て最長距離が短いという特徵があり, かつ, 最長距離が短い病棟の 看護師の方が作業環境への評価が低いという逆転の傾向がみられた。 [内科中度]-「5)作業環境はよい」と最長距離（表 2 , 図 6 [13]）【複 廊下 NS 端】, 【複廊下 NS 中央】は最長距離が短い場合に(5)作業環境 はよい，の評価值が高い傾向がみられた。一方【中廊下 NS 中央】は, 最長距離が $30 \mathrm{~m}$ までに分布しており，他の平面類型に比べて最長距 離が短いという特徴があり, かつ, 最長距離が短い病棟の看護師の 方が作業環境への評価が低いという逆転の傾向がみられた。

[内科中度]·「10機材や物品をスムーズに動かせる」（表 2, 図 6 [14]）

【複廊下 NS 端】,【複廊下 NS 中央】は最長距離が短い場合に(10機材 や物品をスムーズに動かせる，の評価值が高い傾向がみられ，【中廊
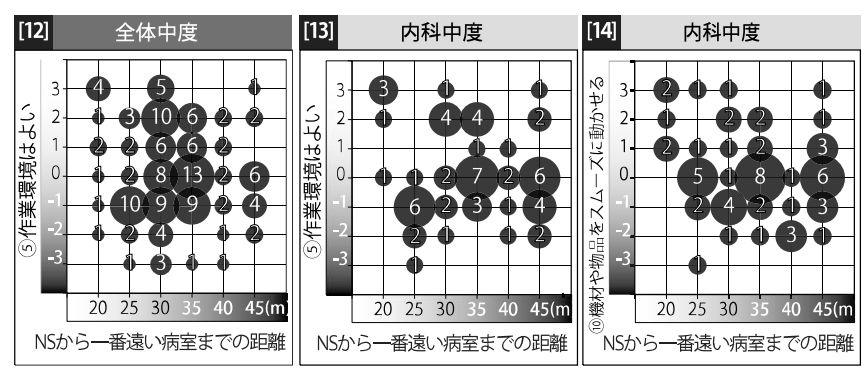

図 5 最長距離之評価の関係

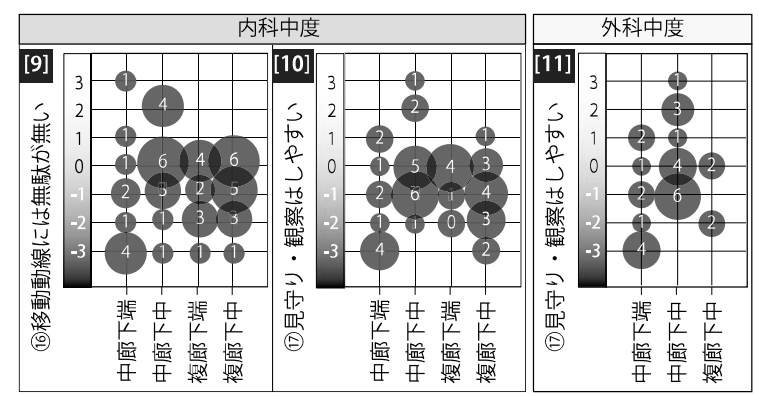




\section{[12] 全体中度「の作業環境はよい」と最長距離：平面頪型ことと}
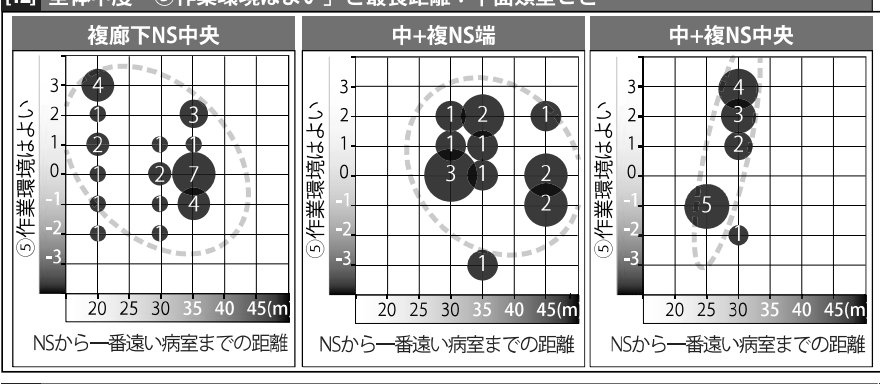

[13] 内科中度「55作業環境はよい」と最長距離：平面類型ことと
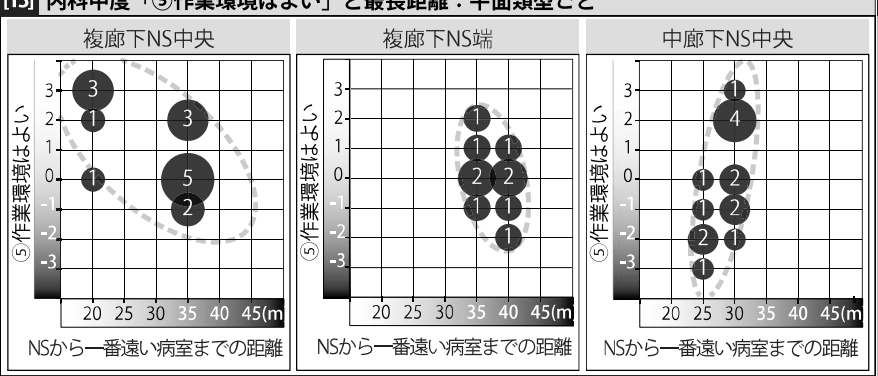

图6 最長距離と評価の関係:

下 NS 中央】では最長距離と評価值に関連がみられない。平面類型に よって，距離と評価との間に関連がみられる場合と，みられない場 合があることから, NS から病室までの距離だけでなく, 平面類型が 負担感に一定の影響を与えていると考えられる。

4.「116移動動線に無駄がない」「17見守り・観察しやすさ」の評価 と平面類型の関係

看謢師視点での病棟の使いや寸さの観点からは一般的に看謢動線 が短いことと，見守り・観察のしやすさが重視される。また，内科 中度, 外科中度にて評価項目の因子分析を行うと, この両者が同じ 因子として同様の関連度で働いている注 12)。図 7 で, ここまで分析 してきた内科中度, 外科中度と, 加えて次に回答が多い整形外科中 度での「16移動動線に無駄がない」「17見守り・観察はしやすい」と 病棟平面との関係をみると，いずれにおいてもここまでの分析と同 様に【中廊下 NS 中央】の類型で比較的高い評価での回答分布が多い ことがわかる。ここで(3)診療科で類似の傾向がみられるのは, 注 5 で記載するように混合病棟の重複の影響も考えられるが, 単科で中 度に限る場合には図 8 の右側のように十分なサンプル数が得られな い。以上より, 診療科を内科, 外科に絞り, また混合病棟の重複を 許しても大きな傾向に矛盾がないと考えられるため, 以下では内科, 外科に絞って分析を続ける。また， 3．3，2）の通り最長距離と評 価との間の関連性は得られていない。そこで, ここでは看護師視点 での病棟の使いやすさの観点を主に「17見守り・観察はしやすい」 に代表させて, 病棟の平面類型との関係を詳細に分析することとす る。なお分析対象は診療科や患者属性を問わず, 回答時に読み取り 可能な平面図が添付されており分析が可能な全病棟とする。

\section{1 「17見守り・観察はしやすい」の評価の平均値からみる病棟} への評価の特徵

(17)に対する看護師の評価得点の病棟ごとの平均值注 ${ }^{13)}$ が，上位 $25 \%$ (四分位) と，下位 $25 \%$ の平面類型の割合を示した（図 8 )。

上位 $25 \%$ に含まれる割合は【中廊下 NS 中央】全 67 病棟中 26 病棟, 【中廊下 NS 端】全 18 病棟中 7 病棟で, この 2 類型が他の類型に比し

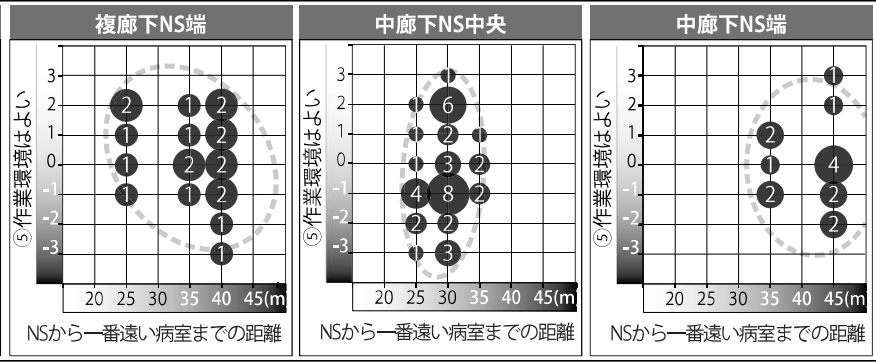

[14]内科中度「10機材や物品をスムーズに動かせる」と最長距離：平面類型ごと

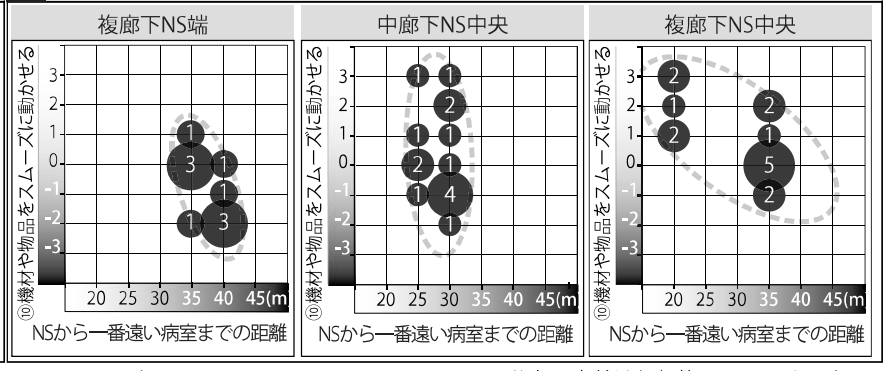

平面類型ごと

ー分布の定義は信頼楕円 $90 \%$ によるもの

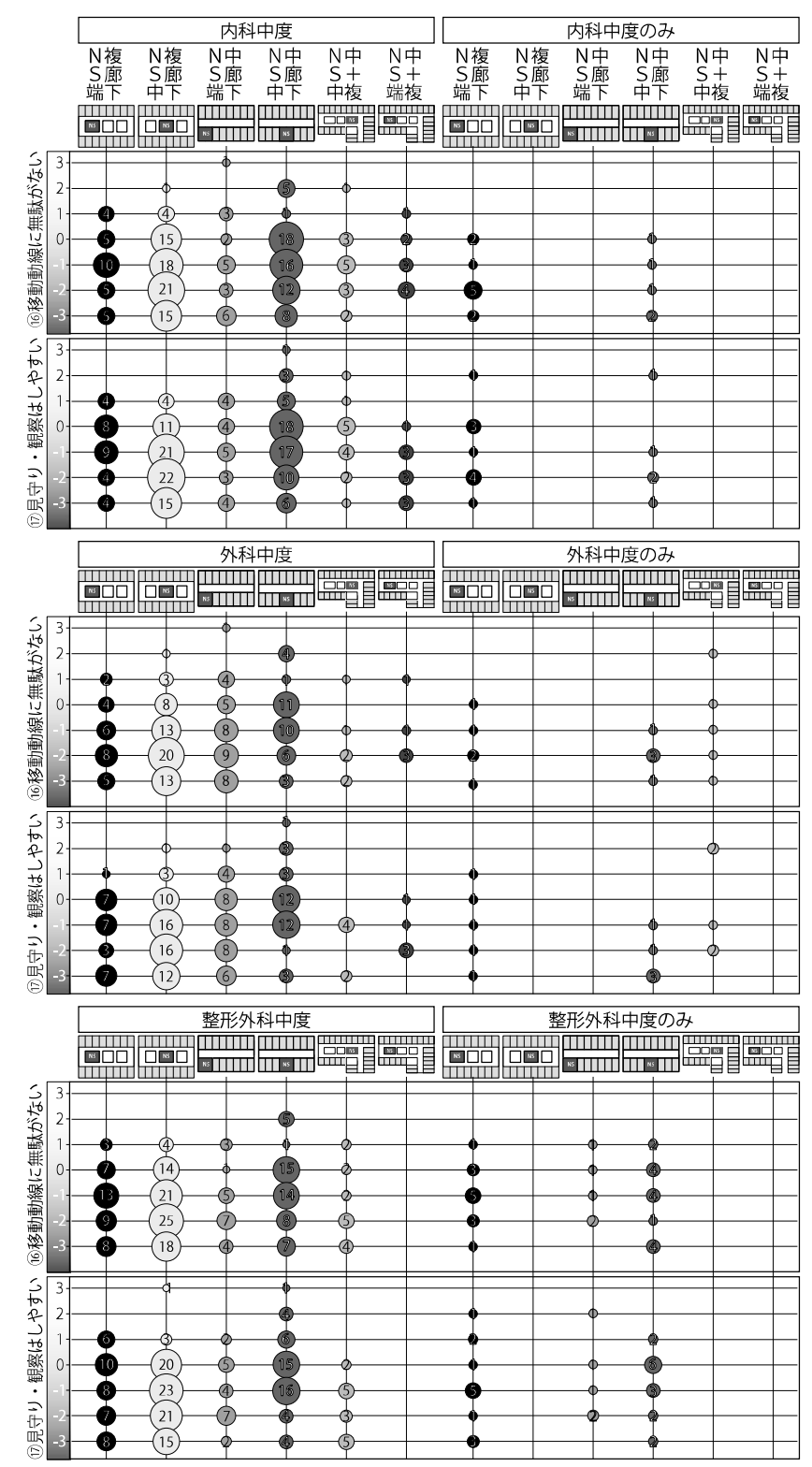

図 7 3 診療科での移動と見守りしやすさへの評価と病棟平面の関係 
て高い。図から，概ね NS の位置によらず廊下の構成で大きな傾向が あり，【中廊下型】>【複廊下型】ミ【中+複型】の順に「(17)見守り・ 観察はしや寸い」と評価されている事が分かる。

下位 $25 \%$ に含まれる割合は, 【中+複 NS 端】全 8 病棟中 4 病棟, 【中 + 複 NS 中央】全 34 病棟中 16 病棟で高く, 最も低い【中廊下 NS 端】 で全 18 病棟中 3 病棟であった。概ね NS の位置によらず【中廊下型】 $<$ 【複廊下型】く【中+複型】の順に含まれる割合が高いことから， 上位 $25 \%$ と同様と読み取れ, 総じて中廊下型の評価が高いと言える。

\section{2 「17)見守り・観察はしやすい」の平均値と病棟平面の関係}

図 8 より近年竣工事例が多い【複廊下 NS 中央】と（図 1), 前項 にて総合的に評価が高い【中廊下 NS 中央】について117の評価が上位 $25 \%$ と下位 $25 \%$ である病棟の平面図を詳細にみる。

\section{1 ）「(17) 見守り・観察はしやすい」の評価と最長距離の関係}

図 10 にて「17見守り・観察はしや寸い」の評価が下位 $25 \%$, 上位 $25 \%$ に該当する病棟を対象に，平面類型と最長距離との関係をみる。 【複廊下 NS 中央】、【中廊下 NS 中央】ともに，(17)の評価が下位 $25 \%$ で ある病棟よりも，上位 $25 \%$ である病棟の方が最長距離が短い傾向が みられた。つまり，おおまかには最長距離が短い場合に，見守り観 察がしやすい傾向であると読夕取ることができるが，統計上の有意 差がみられず，明確な関連があるとは言えない。

2 ）「17見守り・観察はしやすい」の評価とNS からの病室の見通し のしやすさの関係

既報 ${ }^{13)}$ にてNS からの病室の見通しのしやすさが看護負担感へ与 える影響の可能性を述べた。それを踏まえ，「17見守り・観察はしや
寸い」の評価，上位 $25 \%$ と下位 $25 \%$ に該当する病棟の NS から病室 の見通しの可否の割合を示し，関連をみる（表 3 )。このとき, NS の 中から病室の出入り口が 1 以上見える場合を見守りができる, とし て平面図の読み取りを行った。

【複廊下 NS 中央】、【中廊下 NS 中央】ともに上位 $25 \%$ の病棟では NS からの見通しができる割合が比較的高い $(80 \% ， 65 \%)$ が，下位 $25 \%$ 病棟ではNS からの見通しの可否の割合がいずれも $50 \%$ にとど まった。これにより，見守り観察がしやすいとされた病室では，NS から病室を見通せる構成の割合が高く, NS からの病室が見えること と見守り観察のしや寸さとの関係が読み取れるものの, NS から病室 が見通せない構成でも必ずしも見守り・観察がしにくいと評価され る関係ではないことが分かる。

\section{3) ベッド数と(17)見守り・観察のしやすさの関係}

距離や見通し以外の評価に関わる建築的要因として, ベッド数（病 棟の規模）があげられる。【複廊下 NS 中央】ではベッド数と評価と の関連がみられ，下位 $25 \%$ の病棟でベッド数が多く，上位 $25 \%$ の病 棟のベッド数の少ない傾向がみられた (図 9)。そこで,ベッド数と「117 見守り・観察はしや寸い」の関係を図示寸ると（図 12）,【複廊下 NS 中央】では相関係数 $\mathrm{r}=-0.32$ の負の関連がみられ，ベッド数が多 い時, 負担感が大きい傾向がみられた。また,【中廊下 NS 中央】に ついても, ベッド数と「17見守り・観察はしやすい」の関係をみる と相関係数 $r=0.069$ と相関がみられず, ベッド数と負担感の関連 がないことがわかる。特徴的なのはベッド数が多くても見守り・観 察への評価が比較的高い回答者が分布している点で,【中廊下NS 中央】

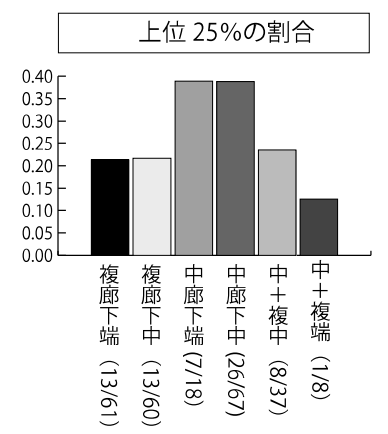

下位 $25 \%$ の割合

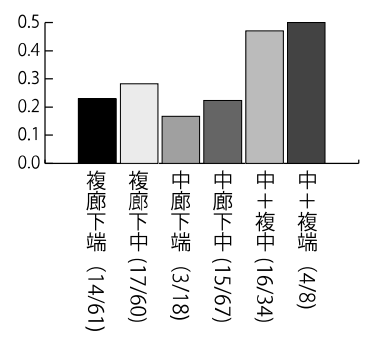

図 8

上位 $25 \%$ と下位 $25 \%$ の平面類型の割合

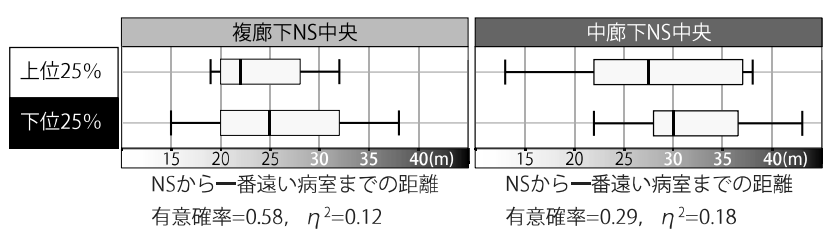

図10「17見守り・観察はしやすい」の評価と最長距離の関係

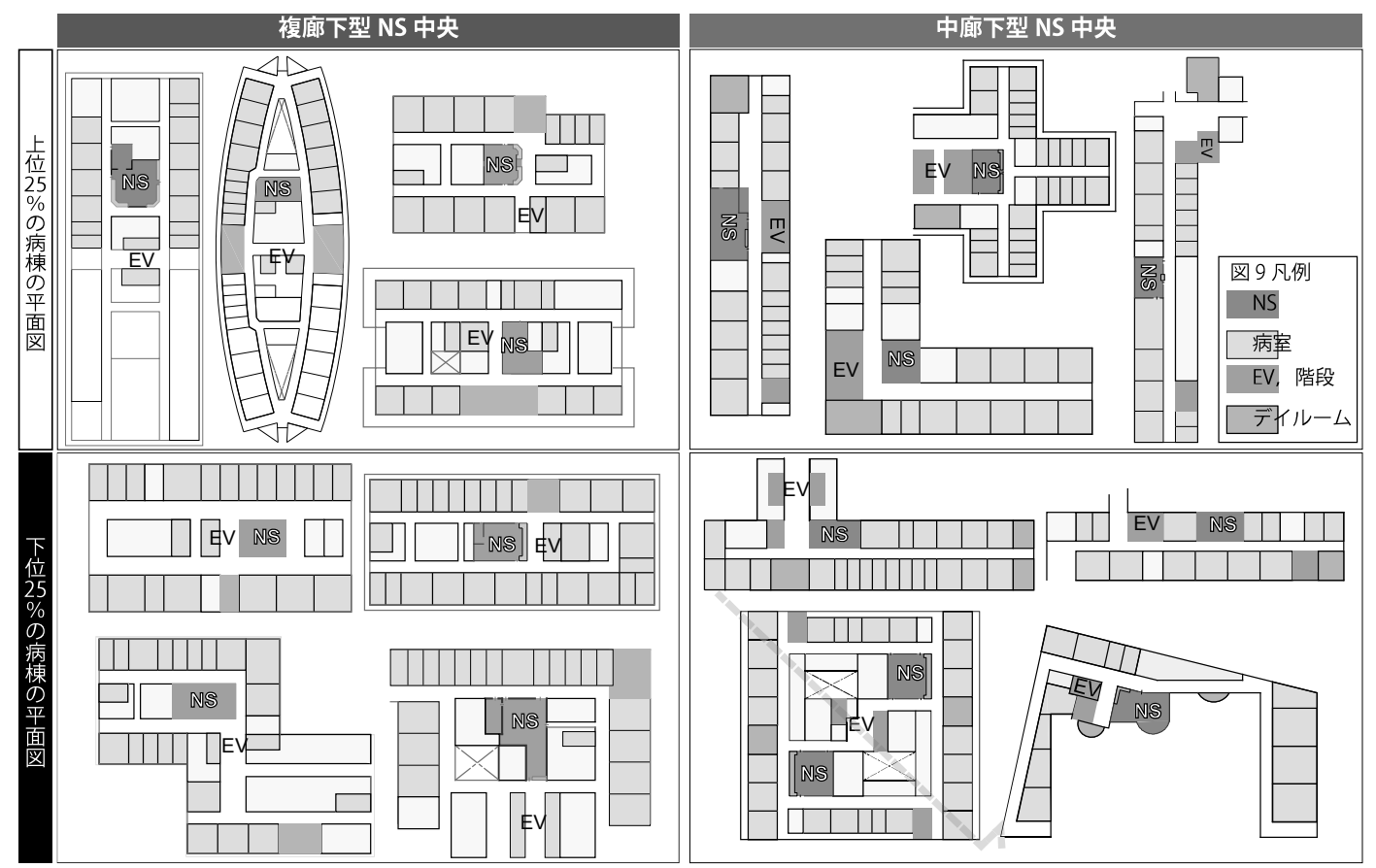

図 9 「(17)見守り・観察はしやすい」の評価の平均值が上位 $25 \%$, 下位 $25 \%$ の平面図

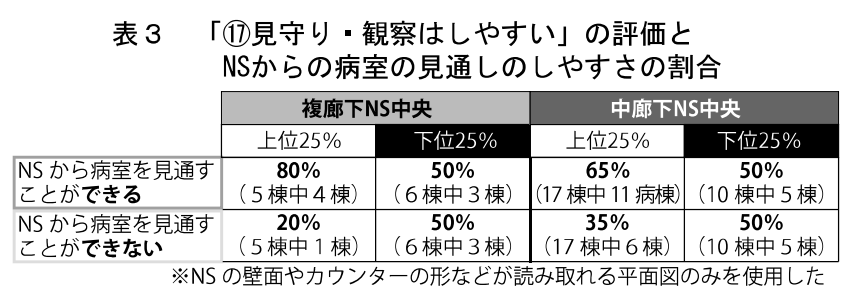


の場合, ベッド数が多くても見守り・観察に対する負担感が必ずし も増さない傾向が指摘できる。

\section{3 【中廊下 NS 中央】での病室向かい合わせ率と評価}

\section{1)【中廊下 NS 中央】での病室向かい合わせ率と評価の関係}

ここまで，最長距離，見通し，ベッド数と分析をしてきた。さら に中廊下型の場合には，病室とその他諸室の関係にも特徵がある。 そこで, ここまでの分析で総合的にみて相対的に最も負担感が低い という評価の数值が得られている【中廊下 NS 中央】について，より 詳細に平面構成をみると, その平面を構成する廊下は病室とリネン 室やトイレなどの病室以外の諸室と向かい合っている［片病室］と， 病室同士が向かい合っている [両病室］に分けられる（図 11）。両 者の長さの割合を病室向かい合わせ率として, “[両病室］廊下の全 長距離／病棟内廊下の全長距離”で求めた。図 9 を詳細にみると下 位 $25 \%$ の病棟は病室が向かい合わない［片病室］廊下の割合が高い 傾向がみられる。上位 $25 \%$ の病棟は病室が向かい合う［両病室］廊 下の割合が高い傾向がみられた。さらに，病室が向かい合う廊下の 割合と「17見守り・観察はしや寸い」「「16移動動線には無駄がない」 との関連をみる (図 13)。両項目とも病室向かい合わせ率が高い（[両 病室］廊下の割合が高い）場合，見守り観察の評価が高く，移動動 線に無䭾がないと評価される傾向がみられた。

2)【中廊下 NS 中央】での病室向かい合わせ率と最長距離の組み合 わせに見る評価との関係

【中廊下 NS 中央】において, 最長距離と病室向かい合わせ率との 関係をみる。さらに 2 変量の分布を，2 軸それぞれの分布が大きく

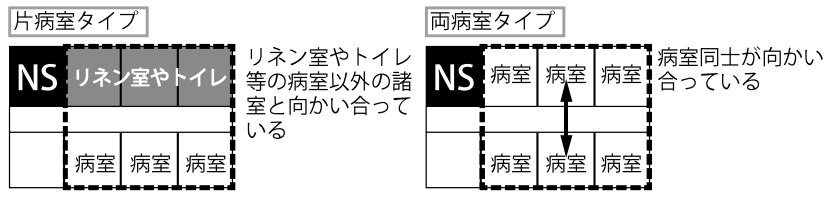

図 11 中廊下型のうち, 片病室と両病室の平面
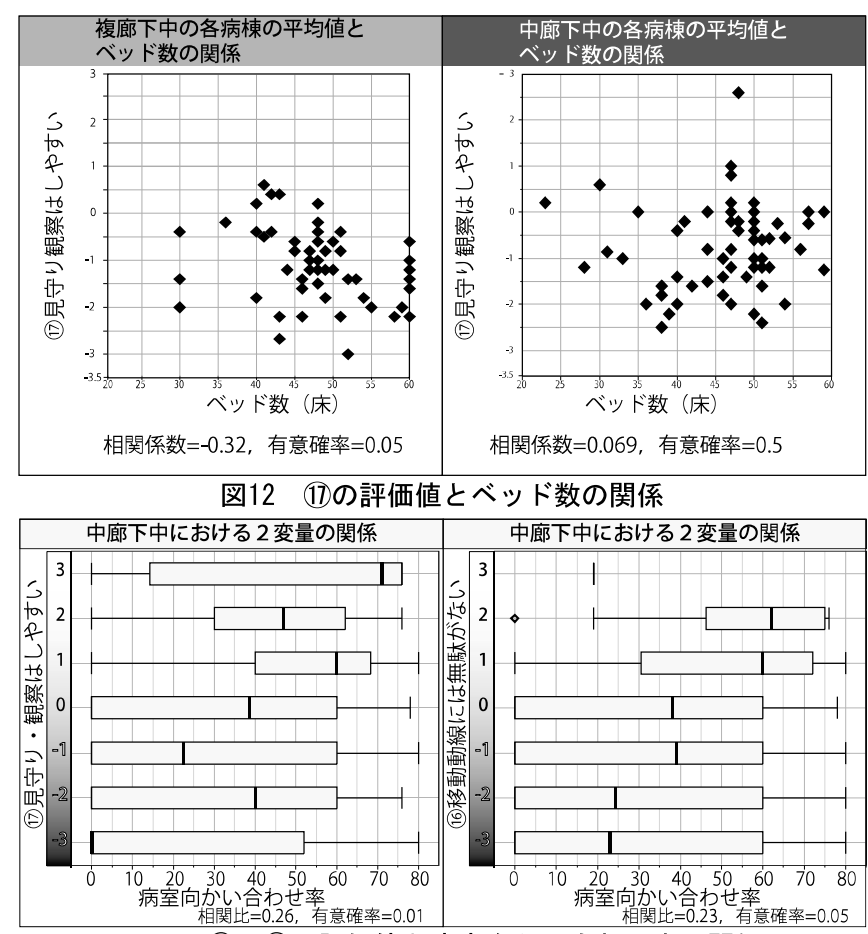

図13 16, 17の評価値と病室向かい合わせ率の関係
2 つの集団に偏る構造を成していることから，その中間の裾を中心 にとって 4 つに分割した。NS から病室までの最長距離が $35 \mathrm{~m}$ 以上, 病室向かい合わせ率 $32 \%$ 以上を [ 第 1 象限 ], 最長距離が $35 \mathrm{~m}$ 未満, 病室向かい合わせ率が $32 \%$ 以上を [ 第 2 象限], 最長距離が $35 \mathrm{~m}$ 未満, 病室向かい合わせ割合が $32 \%$ 未満を [ 第 3 象限 ], 最長距離が $35 \mathrm{~m}$ 以上，病室向かい合わせ割合が $32 \%$ 未満を [ 第 4 象限 ] と分類した。 この分類と「(11)移動動線には無駄がない」,「17見守り・観察はしや すい」との関連をみる（図 14）。

「16移動動線には無駄がない」ではおおむね [ 第 4 象限 $]<[$ 第 3 象限 ], [ 第 1 象限 ] $<$ [第 2 象限 ], [ 第 3 象限 ] $<$ [ 第 2 象限 ], [ 第

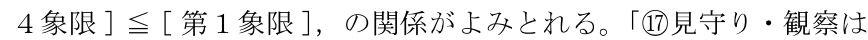
しや寸い」ではおおむ放 [ 第 3 象限 ] < [ 第 4 象限 ] < [ 第 1 象限 ] $<$ [第 2 象限 ] の関係がよみとれる。大まかな傾向としては，一般 的に言われている, 最長距離が短いことに加えて, 病室向かい合わ せ率の高い病棟で負担感が低い傾向が指摘できる。これは，実際に そのように動くか（実際の看護動線）については不明だが，病室を 移動しての 1 動線での看護が可能であることへの反応，あるいは同 僚看護師の動きを把握しや寸いことへの反応と考えられる。

\section{5.まとめ}

本稿で得られた知見を以下にまとめる。

\section{1 評価項目との関係}

\section{1 ）看護師の勤務に関連する諸条件}

看護師の勤務に関連する諸条件と評価項目の関係は日勤勤務時間 と「(1)仕事量が多く負担である」,「(11)看護記録を書く時間はある」,「12 休み時間は十分にとれている」との関連はみられるが，「(16)見守り・ 観察はしやすい」や「117移動動線には無駄がない」等の動線や看護 のしやすさに関する項目との関連はみられず，看護師の勤務関連の 諸条件が動線や看護しやすさの項目に影響しない傾向が読み取れた。 2 ) 内科, 外科に限定した場合

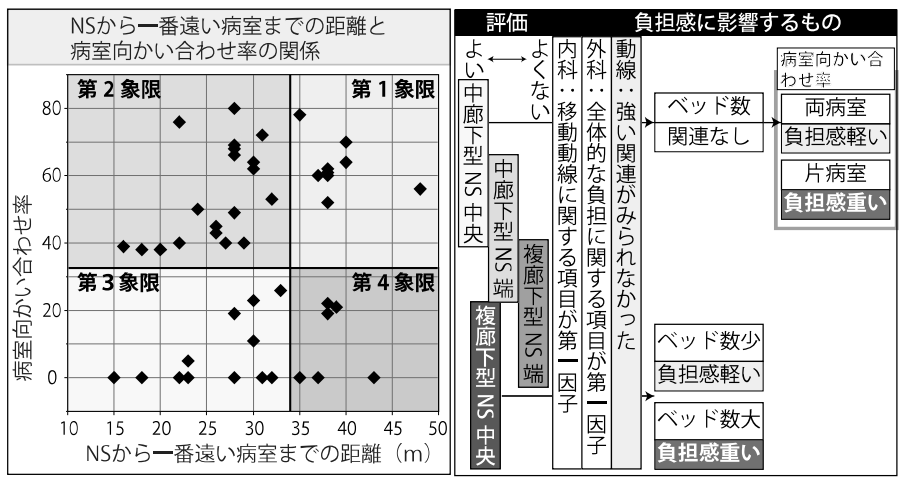

図14 2 変量の象限

図16 本研究で得られた知見

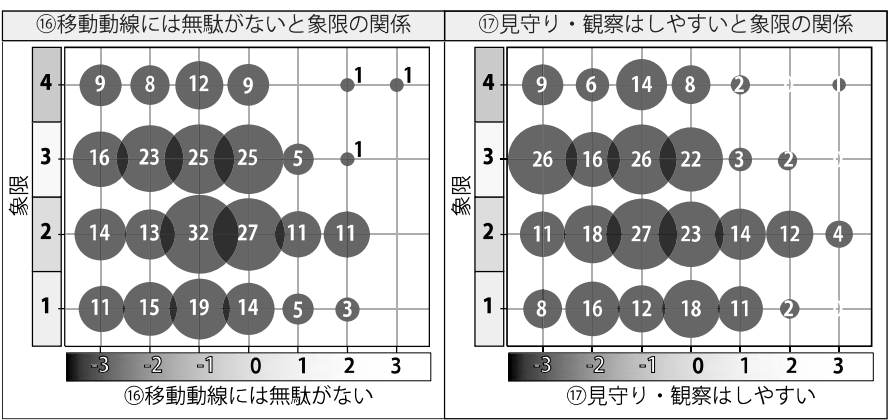

図15 象限と(16), (17)の評価値の関係 
内科と外科の看護師に限定した評価項目と平面類型の関係は, 内 科のみの看護師では, NS が中央の場合, 作業環境はよいと評価され る傾向がみられ，また内科，外科ともに総合的に【中廊下 NS 中央】 の評価が高い傾向がみられた。

3）全体中度, 全体重度, 内科中度, 外科中度に限定した場合

[全体中度］は【NS が中央】、【中+複 NS 中央】で負担感が軽い看 護師が比較的多い。[全体重度］は吹き抜けがあり，【複廊下 NS 中 央】で負担感が軽い看護師が比較的多い。[内科中度], [外科中度 ] は【中廊下 NS 中央】で負担感が軽い看護師が比較的多いことがわかっ た。平面類型において総合的にみると【中廊下 NS 中央】の看護師の 負担感が少ない傾向がみられる。病棟平面の計画史において, 一般 に総室型 $\rightarrow$ ベイ型 $\rightarrow$ 中廊下型 $\rightarrow($ 派生) 複廊下型 $\rightarrow$ (派生) 回廊型と, 病室の独立と看護動線の短縮の観点から発展型として説明されてき た複廊下型であるが，その評価は看護負担感の関係からは必ずしも 高いとはいえないことが分かった。

口最長距離最長距離と評価項目は, 「(5)作業環境はよい」や「(10) 機材や物品をスムーズに動かせる」等の動線に関連する項目との [ 弱 い関連］がみられた。最長距離が短い場合に, 負担感が軽い看護師 が比較的多い傾向がみられたが，「(5)作業環境はよい」への評価は, 最長距離が短い場合でも評価值が低い回答者がみられた。

口病棟平面類型との関連 平面類型によって, 最長距離と「(5)作 業環境はよい」,「(10機材や物品をスムーズに動かせる」の評価項目 との間に, 関連がみられる場合とみられない場合があることから, NS から病室までの距離だけでなく, 平面類型が負担感に一定の影響 を与えていると考えられる。

\section{2 [内科中度 ] と [ 外科中度 ] の評価因子と病棟平面の関連}

[内科中度 ] の第 1 因子は移動動線を主とした看護負担感因子, [ 外 科中度 ] の移動動線関連項目は第 3 因子であった。また, [内科中度 ] は【複廊下 NS 中央】, [外科中度 ] は【中廊下 NS 中央】の因子評価 得点が最も高い。因子軸の違い, 評価される平面類型の違いは, 患 者の高齢化や患者の重症度ではなく, 診療科の特徴であると考える。

\section{$5.3 「(17)$ 見守り·観察はしやすい」の評価と【中廊下 NS 中央】【複}

\section{廊下 NS 中央】}

「17)見守り・観察はしやすい」の評価を上位 25\%，下位 25\%に分 類すると, 【中廊下 NS 中央】 は上位 $25 \%$ に多く, 下位 $25 \%$ に少ない 傾向がみられた。「17見守り・観察はしや寸い」に関して【中廊下 NS 中央】の評価が高い傾向がわかる。

\section{1) 最長距離}

【複廊下 NS 中央】, 【中廊下 NS 中央】ともに, 最長距離が短い時, 見守り観察はしやすいと回答する傾向がみられたが, 明確な関連が あるとは言い切ることはできない。

\section{2) NS から病室の見通しのしやすさ}

【複廊下 NS 中央】,【中廊下 NS 中央】ともに, 上位 $25 \%$ の平面は比 較的NS から病室の見通しがしや寸い傾向がみられたが，下位 $25 \%$ の 平面は, NS から病室が見通しができるものと, できないものが混在 していた。NSからの見通しは見守り観察に影響を与えることが示唆 されるが，NS から病室を見通せることが，必ずしも見守り・観察の しやすさへの評価をよく寸るとは限らない。

\section{3 )【複廊下 NS 中央】【中廊下 NS 中央】でのベッド数と評価}

ベッド数が看護負担感に影響することが確認でき, 病棟全体のベッ
ド数が少ない時, 見守り観察はしやすいと評価されている。【複廊下 NS 中央】でベッド数が多い場合, 負担感が大きい傾向がみられたの は，ベッド数が多いことで多くの患者を看護するという精神的負荷 が「見守り・観察はしやすい」の負担感に影響を及ぼしていると考 える。対照的に【中廊下 NS 中央】の場合, ベッド数が多くても「17 見守り・観察はしや寸い」の得点に影響がない点が特徵的である。

\section{4 )【中廊下 NS 中央】での病室向かい合わせ率と評価}

病室向かい合わせ率が看護負担感に影響する可能性が高いことが わかった。[両病室］廊下の割合が高い時, 見守り観察の評価值が高 い傾向がみられた。看護業務をする際, 向かい合わせに病室がある 事で, 効率よく業務を行うことができる点が見守り・観察のしやす さにつながるのではないかと考える。【中廊下 NS 中央】の「16移動 動線には無駄がない,「17見守り・観察はしやすい」の評価項目に 関し, 最長距離が短いことに加えて, 病室向かい合わせ率の高い病 棟で評価が高い傾向が指摘できた。

\section{4 総括}

本研究にて, 平面類型によって「(5)作業環境はよい」,「(16)移動動 線には無駄がない,「17見守り・観察はしやすい」等の移動動線に 関する看護負担感が異なることが指摘できた。また, 病棟平面の計 画史において発展型として考えられており近年の竣工事例も多い【複 廊下型】は, 看護負担感の観点から必ずしも高く評価されていると は言えず，総じて【中廊下型】の評価が比較的高いという特徽的な 結果を得た。病室とNS の最長距離も看護負担感との間に明確な関連 はみられず, 最長距離を要因としての “看護動線短縮 = 看護負担感 の軽減”という単純な関係では説明ができなかった。しかし，中廊 下型病棟では［両病室］廊下の割合が高いときに看護負担感が低い 傾向があった。ここから,これまで病棟の平面計画で重視されてき た看護動線の短縮について, 看護負担感の観点からはNS から最も遠 い病室までの距離よりも 1 動線での看護の効率の方が説明しやすい 可能性を指摘した。また【中廊下 NS 中央】ではベッド数が多くても 看護負担感が必ずしも高くない点が特徵的で，こうした点は病棟計 画に資する知見であると考える。

今回の分析では, 対象を関東圈の病院に限定しており患者の高齢 化が特に著しいと言われる地方の病院など条件が異なる場合に同様 の傾向が指摘できるか不明であり, この点は今後のさらなる検証を 要する。病院ごとの特性注1) や診療科による評価傾向の差異につい ても，十分な説明には事例が不足している。また，病棟内 NS の設定 において廊下と一体化したナーシングホール型とも表現できる事例 なども近年竣工しており, こうした新しいプランについての評価や, 医療行為の変化・看護師配置の変化・患者属性の変化など, 明確な 傾向指摘にはさらなる知見の蓄積が必要と考える。

\section{謝辞}

調査にご協力いただきました皆様に改めて御礼申し上げます。な お，本研究は科学研究費補助金（基盤 $\mathrm{A}$ ）：アクセシビリティの視点 による地域医療提供体制の再構築に関する包括的研究（研究代表者 熊川寿郎, 課題番号 23249029 課題番号, 2011-2013）による研究事 業の一部です。 
注

注 1 ) 本調查研究の倫理審查を行った国立保健医療科学院倫理審查委員会で の検討により,「病院名を特定しないこと」が調查実施の条件として課され た。このため, アンケート回答時には病院名称は問うておらず、病院名の 同定につながる立地・機能・総病床数の質問も避けた。結果的に, 同封し た同意書への病院名称付き返答によって病院名が同定可能なケースが含ま れたが, アンケート回答と同意書記載の病院名の紐付けは行わない取り決 めに従い, 処理した。調查研究の精度向上のためには, 病院の立地や機能, 規模等の偏りなどについても検討すべきであるが，本調査については枠組 み上のやむを得ない事情により,この分析は断念した。この病院ごとの特 性による検討が行われていない点を本稿の限界として記する。

注 2 ) アンケート調查結果の単純集計は付図 2 の通り。

注 3 ) 看護師全数に対する調查を依頼した場合, シフト等の関係で各病棟で のアンケート趣旨説明・配布・回収が煩雑になり, アンケート回収率が極 端に下がることが予測された。本稿が主眼を置く病棟平面と看護負担感の 関係の分析のためには, 少数の病棟から数多くの看護師評価を得ることよ りも, 多数の病棟から比較的少数の看護師評価を得る方が比較の確からし さを増すと考えられる。このため, 看護師評価の回収総数よりも病棟ごと の回収数を增やすことを優先し, 対象看護師数を病棟ごと日勤看護師 10 人 前後の約半数からの回収と想定してアンケート配布・回収を一日で行える よう, 各病棟 5 人という調查設計を行った。

注 4）職業性ストレス簡易調查票は, 平成 $7 \sim 11$ 年度労働省（当時）研究課 題「作業関連疾患の予防に関する研究」に扔ける東京医科大学公衆衛生学 講座のストレス測定グループによる研究成果物である ${ }^{16)}$ 。現在は無償で公 開されており, 日本看護協会での労働環境の改善の推進に際してもストレ スチェックの方法として紹介されている ${ }^{17)}$ 。職業性ストレス簡易調查票に
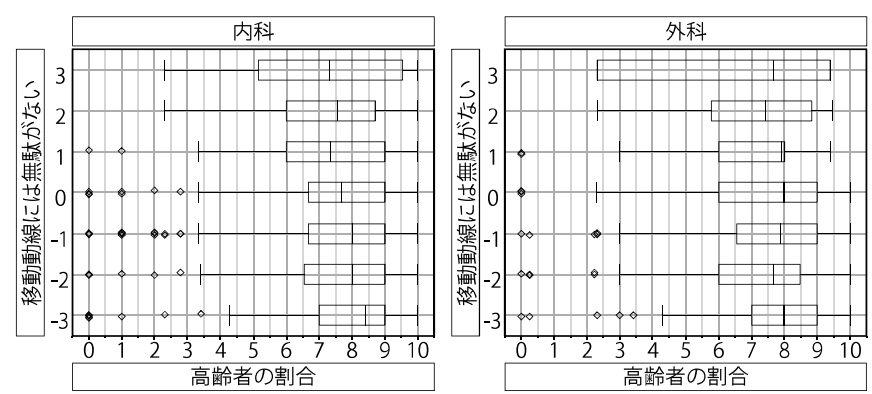

付図 1 診療科と患者の高齢化率
よる調查結果は, それぞれの職場でのストレス軽減への取り組みなどによっ て変化しうるものであるが，本稿が主眼とする病棟平面との関係において は, “ある型の平面でのみストレス軽減への取り組みが行われている（例え ば中廊下型平面でのタストレス軽隇への取り組みが行われており中廊下型 平面のストレス評価值が他に比して軽く計測される)”という状況は想定し にくい。このため, ストレス軖減への取り組みの有無等による差異は, 事 例間で相殺され本稿の分析には関わらないと判断する。ただし, 注 3 にも 記したように回答した看護師の人数が病棟看護師の全数ではない点, また 注 1 に記したように病院ごとの立地や機能等による偏倚の確認を行ってい ない点などは, 本稿の手法上の限界として認識されるべきである。このこ とから, 本稿知見はこの調查手法拉よび回答者における限定的分析結果と して報告されるものであり, ストレス評価值の測定において普遍性を担保 するものではない旨，記す。

注 5 ) 診療科ごとの回答件数（病棟ごとの対象診療科）の詳細は下の図の通 り(付図 3 )。単科診療科の病棟は, 全体数に比べて多数ではない。このた め, 単科に限ると分析対象数がごく少なくなるため, “その診療科の看護を 行う病棟”と解釈することとし，混合病棟を含む分析を行うこととした。

注 6$)$ 相関比の相関の值について ${ }^{18), 19)}, 0.25$ 未満; 非常に弱く関連している ／0.25０.5; やや弱く関連している／0.5〜0.8; やや強く関連してい る $/ 0.8 \sim 1.0$; 非常に強く関連している

注 7 ）クラメールの独立係数の值について $\left.{ }^{16)}, 17\right), 0.25$ 未満; 非常に鸧く関連 している $0.25 \sim 0.5$; やや弱く関連している $0.5 \sim 0.8$; やや強く関 連している $/ 0.8 \sim 1.0$; 非常に強く関連している

注 8 ）例えば内科では高齢患者の割合が高い，など診療科ごとの患者の年齢 による影響も検討したが，高齢者の割合と評価の間に明確な関係は見られ なかったため, ここでは救護区分に代表させることで十分と判断した。付 図 1 に, 内科と外科での「16移動動線に無䭾がない」への評価と高齢者の 割合の関係を例示する。

注 9 ) 救護区分; 「担送」自力歩行が不可能な状態, 「護送」自力歩行が可能だが, 救護活動時の自力歩行は危険な状態「独歩」自力歩行が可能な状態を指す。 注 10）得られた平面図のうち, 縮尺や寸法が記載されていた図面より平均間 口を算出して用いた。

注 11）SPSS ソフトの最尤法のプロマックス回転により分析

注 12）内科中度, 外科中度で 16 の評価項目を元にした因子分析を行うと, 内 科中度では第一因子として(16)177)含省移動動線を主とした因子, 外科中度

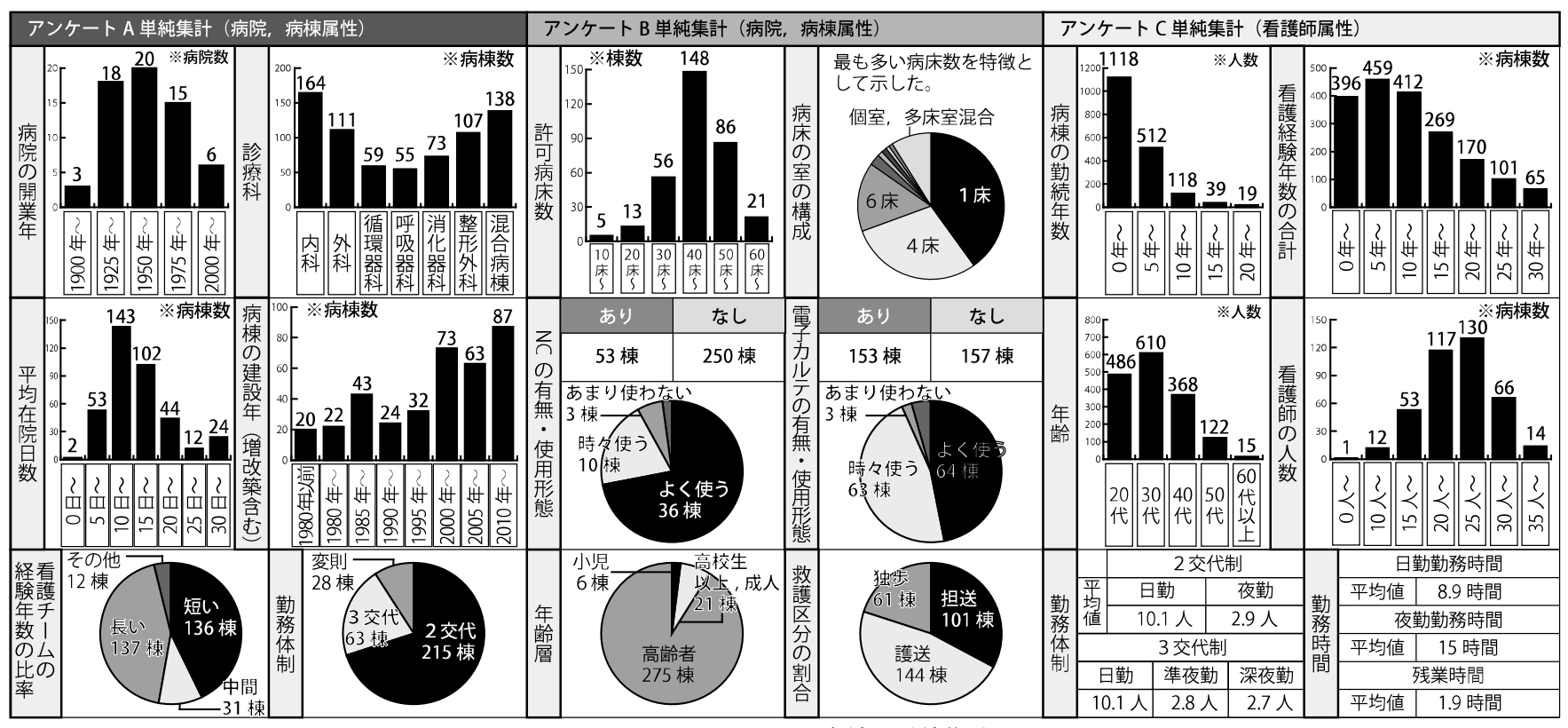

付図 2 アンケート調査結果単純集計 


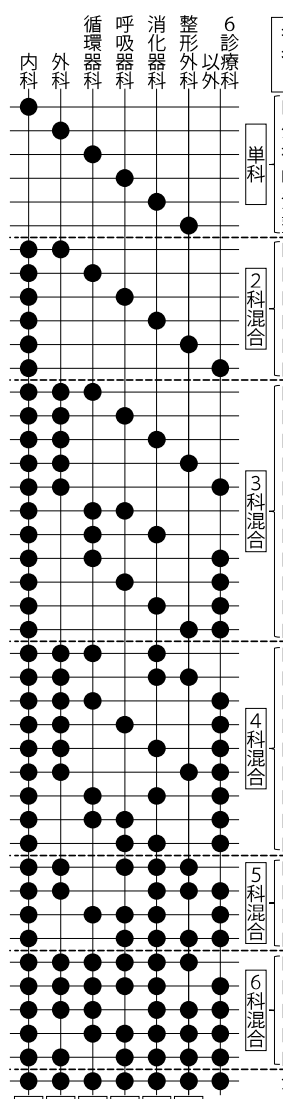

回答病棟数, 回答看護師数

*全体／中度に限る，の順で記載。/の表記がない場合は中度 に該当なし

内科峃科 : 33/6病棟，152/26人

外科単科 : $13 / 6$ 病棟， $72 / 37$ 人

盾環器科単科 : $8 / 6$ 病棟, $40 / 30$ 人

呼吸器科単科: $3 / 2$ 病棟, $15 / 10$ 人

消化器単科: $8 / 4$ 病棟, $40 / 20$ 人

整形外科緹科: 21/11病棟, $105 / 55$ 人

内科・外科混合 $: 8 / 2$ 病棟, $43 / 15$ 人

内科・循環器科混合：3 病棟, 14 人

内科・呼吸器科混合: 2 病棟, 10 人

内科・消化器科混合 : 1 病棟， 5 人

内科・整形外科混合： $8 / 4$ 病棟，43/22人

内科・他診療科混合：19/6 病棟，95/25

内科・外科・循環器科混合 : $2 / 1$ 病棟, $10 / 5$ 入

内科・外科・呼吸器科混合: 1 病棟, 5 人

内科・外科・消化器科混合: $2 / 1$ 病棟， $10 / 5$ 人

内科・外科・整形外科混合: $7 / 2$ 病棟，37/10人

内科・外科・他診療科混合: $4 / 2$ 病棟，19/10人

内科・徝環器科・呼吸器科混合: $3 / 1$ 病植 $15 / 5$ 人

内科・徝環器科・消化器科湿合: 1/1 病榑 $5 / 5$ 人

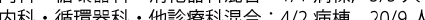

内科・偱猿器科・他診療科混合: 4/2 病棟, $20 / 9$ 人

内科・消化器科・他診療科混合: 7/2 病棟, 35/10人

内科・整形外科・他曢科混合: $7 / 4$ 病棟, $44 / 20$ 人

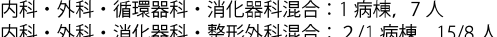

内科・外科・消化器科・整形外科混合：2/1 病棟，15/8 人

内科・外科・偱噮器科・他診原科混合: $2 / 1$ 病棟, $10 / 5$ 人

内科・外科・呼吸器科・他診療科混合: $2 / 1$ 病棟， $10 / 5$ 人

内科・外科・消化器科・他診療科混合: $3 / 1$ 病棟， $15 / 5$ 人

内科・外科 $\cdot$ 整形外科・他診療科混合：7/5病棟， $38 / 28$ 人

内科・循環器科・消化器科・他診療科混合：1/1病棟，5人

内科・循環器科- 呼吸器科・他診療科混合: 1 病棟， 5 人

内科・呼吸器科・消化器科・他診療科混合: $2 / 2$ 病棟, $10 / 10$ 人

内科・外科・呼吸器科・消化器科・整形外科混合 : $3 / 1$ 病棟, $19 / 5$ 人

内科・循環器科・呼吸器科・消化器科・他診療科混合: 2 病棟, 10 人

内科·挐吸器科・消化器科・整形外科: 他診療科湿合: 1 病棟, 5 人

- 外・徝環器・呼吸器・消化器・他診療科混合 : 2 病棟, 6 人

内・外・循環器・消化器・整形外・他診療科混合: $2 / 1$ 病棟，10/5人 内・循環器・呼吸器・消化器・整形外・他診療科混合 : $2 / 1$ 病棟, $15 / 5$ 人

内・外・呼吸器・消化科・整形外・他診療科混合: $1 / 1$ 病棟, $5 / 5$ 人
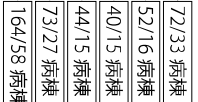

$\infty$

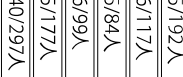

付図3 回答病棟・看護師の対象診療科の組み合わせ

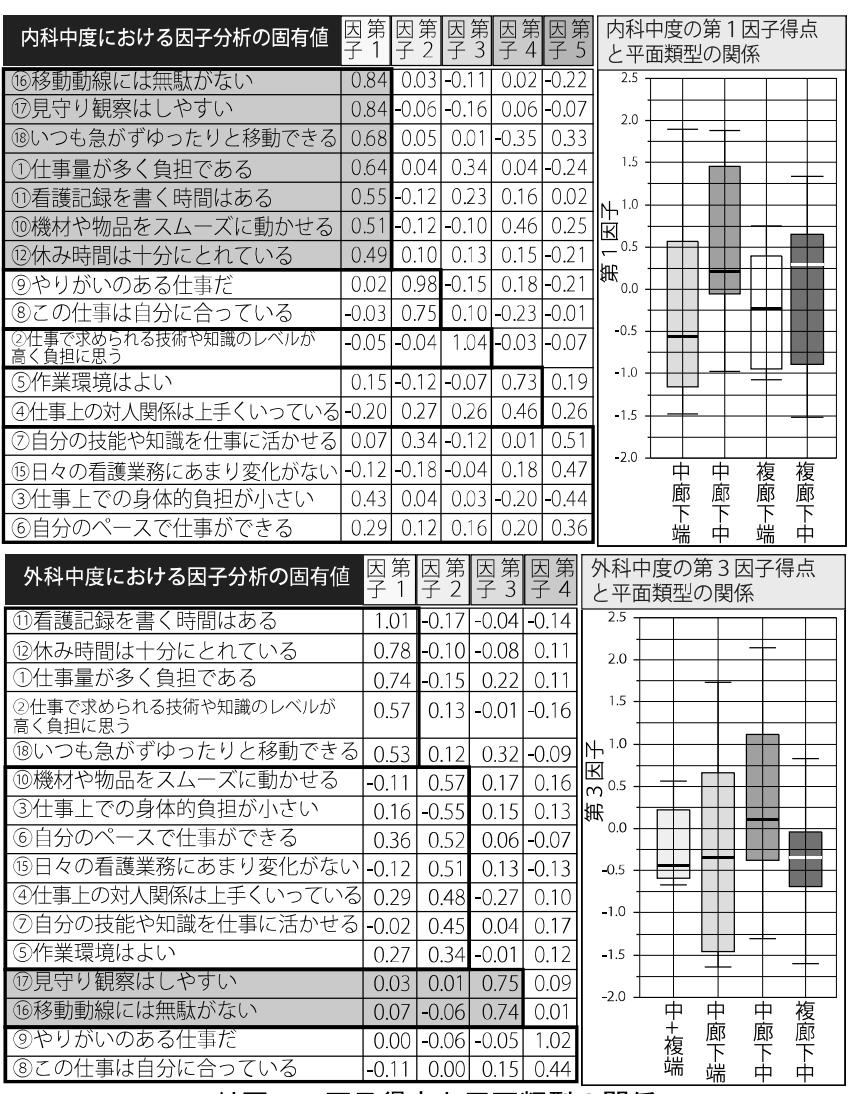

付図 4 因子得点と平面類型の関係
では第三因子として(16)(17)を含む看護動線関連の因子が得られた（付図 4)。 診療科による因子発現の優先度の差異については, より詳細な検討・記述 が必要となるため割愛し別の機会に譲るが，ここでは116移動動線には無駄 がない，と17見守り・観察はしやすいが同じ因子に含まれ，寄与率がそれ ぞれ同程度であることから，評価が連動していることを記する。

注 13）全体的に厳しく評価する，全体的に土0 付近（どちらとも言えない） で振れ幅が少ないなど，回答者個人による回答傾向の差異を除外し病棟ご との大まかな傾向を把握するため, 回答者の評価点の平均值を求めた。

\section{参考文献}

1) 小林健一：近年の病棟計画の動向, 医療福祉建築, N0.150, p. 6, 社団法 人日本医療福祉建築協会, 2006.1

2 ) 長澤泰 : 建築計画 第 3 章 施設を計画する $3 \cdot 1 \sim 3 \cdot 2$ 病院, 市ヶ 谷出版, 2007.10

3 ) 小林健一:テキスト建築計画 第 8 章 診る・治す $8 \cdot 2$ 病院, 学芸出版社, 2010.2

4) 伊藤誠・栗原嘉一郎 : 病棟部の構成と看護単位の大きさ - 病院の建築計 画に関する研究 - , 日本建築学会論文報告集, N0.57, pp. 81-84, 1957.7

5 ) 伊藤誠・栗原嘉一郎・松本光平 : 病棟における看護諸室の性格 - 病院の 建築計画に関する研究 - ，日本建築学会論文報告集，N0.67, pp. 129-136, 1961. 2

6）長澤泰 : 病棟における夜勤看護婦の行為分析 - 病棟の建築計画に関する 研究 -, 日本建築学会論文報告集, N0. 329, pp. 74-86, 1983.7

7 ) 長澤泰: 病棟看護婦の病室訪問頻度の分析-病棟の建築計画に関する研究日本建築学会計画系論文報告集, N0. 361, pp. 42-52, 1986.3

8 ）谷口元 $\cdot$ 柳澤忠 $\cdot$ 今井正次 $\cdot$ 加藤彰一 - 山本和典 $\cdot$ 志田弘二 : 看護動線 量の予測に関する基礎的研究 $-\mathrm{N}$ 病院外科系病棟一の適用 - , 日本建築学 会論文報告集，N0. 344，pp. 116-125，1984.10

9) 中野明・石橋達勇 : 病棟における分散型の看護拠点と物品管理システム SPD 化からみた病棟の建築計画に関する研究-, 日本建築学会計画系論文集, N0. 611 , pp. $31-36,2007.1$

10）河合慎介・勝野幸司 - 今井正次：物品配置からみた病棟看護業務位置 の段階構成に関する基礎的研究，日本建築学会計画系論文集，N0.614, pp. 89-96, 2007. 4

11）鳥山亜紀・渡辺玲奈・中山茂樹・筧淳夫・山下哲郎：「パーソナル看護拠 点」およびその他の看護拠点の機能と配置に関する研究 - 医療・患者情報 の電子化と急性期病棟計画の再検討 その 2-, 日本建築学会計画系論文集, N0. 625 , pp. $527-533,2008.3$

12）久富瑞穂・三木明子・森中恵子 : 職業性ストレス簡易調査票を用いた病 棟別ストレスの経年評価，日本看護学会抄録集 看護管理，N0.37，2006.10

13）上谷ひとみ・山田あすか・山下哲郎・佐藤栄治 : 病棟平面と看護師の看 護負担感の関係に関する予備的調査, 日本建築学会技術報告集, N0.44, pp. 677-682, 2014. 6

14）長澤泰, 須田眞史：病室ベッド配置の変遷，建築設計資料集成 福祉・ 医療（日本建築学会編）, p. 149, 丸善株式会社, 2002.9

15）社団法人日本医療福祉建築協会：保健・医療・福祉施設建築情報シー 卜集 $2009 \cdot 2010 \cdot 2011 \cdot 2012 \cdot 2013$, 社団法人日本医療福祉建築協会, 2009. 9, 2010.9, 2011.9, 2012.9, 2013, 9

16）東京医科大学公衆衛生学講座 : 職業性ストレス簡易調査票, 〈ht t p : // www. tmu-ph. ac/topics/stress_table.php〉, 参照 2014.9. 30

17）日本看護協会：労働環境の改善の推進，〈http：//ww w nurse.or.jp/ nursing/practice/shuroanzen/safety/01.htm1〉, 参照 2014.9.30

18）管民郎：アンケートデータの分析, 現代数学社, 2006

19）田村正紀：リサーチ・デザイン 経営知識創造の基本技術, 白桃書房, 2006 


\title{
STUDY ON THE RELATION BETWEEN HOSPITAL WARD PLAN
}

AND NURSES' BURDEN-FEELING

\author{
Hitomi KAMIYA* , Asuka YAMADA**, Tetsuro YAMASHITA*** \\ and Toshiro KUMAKAWA****
}

\footnotetext{
* Graduate School of Architecture, School of Science and Technology for Future Life, Tokyo Denki University, M. Eng. ** Assoc. Prof., Department of Architecture, School of Science and Technology for Future Life, Tokyo Denki University, Dr. Eng. *** Prof., Department of Architecture, Faculty of Architecture, Kogakuin Univ., Dr. Eng. **** Director, Department of Health and Welfare Services, National Institute of Public Health, Ph. D.
}

Until now, existing architectural planning research on hospital wards has surveyed the volume of nurse traffic and investigated the efficiency of multiple nurse base stations. The Japan Academy of Nursing Administration and Policies (JANAP) has also accumulated a body of research on nurse stress and surveyed their levels of job satisfaction. However, there is little research that has evaluated hospital ward layouts based not on nurses' physical traffic, but on their perception of burden. As mental stress is a problem in nursing and care institutions, we believe it is necessary to evaluate hospital wards from the perspective of this perception of burden. This study clarifies the relationship between hospital ward layouts and nurses' perception of burden. It also verifies the practical convenience of multiple-corridor layouts, which are considered the innovative floor plan for wards.

The targets of this survey were six hospital departments from the six prefectures and one municipality of the Kanto region of Japan. We surveyed nurses on these wards to investigate their perception of burden in terms of the operations of the hospital, the operation of the ward, lines of traffic, and ease of use. Valid questionnaire responses were received from 110 hospitals out of 1,287 (limited to those that included a diagram of the ward layout). We sorted the ward diagrams obtained via the survey into six categories according to whether the wards were organized in a central corridor or multiple corridors, and whether the nurse station was located centrally or peripherally. According to the literature in this field, the "multiple-corridor, centrally-located nurse station" ward has become the most common layout in recent years

Survey results showed that among the various ward layouts, in general the nurses evaluated the "central-corridor, centrally-located nurse station" highly. The multiple-corridor model, considered the innovative ward layout, cannot necessarily be described as beneficial from the perspective of reducing nurses' perception of burden. The axis of evaluation used by the survey respondents differed according to hospital department, and the total distances nurses traveled were not strongly related to their perception of burden. In addition, we considered closely the respondents' answers to the survey question on the ease with which they could observe and keep watch over patients. This item has particular relevance to hospital ward architecture, for wards with the "multiple-corridor, centrally-located nurse station" layout, of which many have been constructed in recent years, and wards with the generally wellregarded "central-corridor, centrally-located nurse station" layout. We found that the respondents evaluated the "multiple-corridor, centrally-located nurse station" wards poorly when there were a high number of beds. In contrast, no relationship was found between number of beds and nurses' evaluations of "central-corridor, centrally-located nurse station" wards. We also identified a tendency for respondents to positively evaluate wards with a "centralcorridor, centrally-located nurse station" layout when a large proportion of wards faced each other and when there was only a short distance between the nurse station and the furthest ward. Nurses' perception of burden seemed reduced when they were able to more efficiently visit many wards due to short distances and had a high ratio of facing rooms. These results indicate different trends than those ascertained by research based on volumes of nurse traffic, and this investigation of ward layouts from nurses' perception of burden can be said to have been effective. 